\title{
ANALISIS KEMAMPUAN BERPIKIR KRITIS DALAM MENYELESAIKAN MASALAH MATEMATIKA DITINJAU DARI GENDER PADA SISWA KELAS VII SMP NEGERI 16 POLEANG TENGAH
}

\author{
Nurmiati $^{1)}$, Jufri $^{2)}$ \\ ${ }^{1,2)}$ SMP Negeri 16 Poleang Tengah. Email: nurmiatibasri20@gmail.com ${ }^{1)}$; \\ jufrimat9@gmail.com²)
}

\begin{abstract}
Abstrak
Penelitian ini bertujuan untuk mengetahui perbedaan kemampuan berpikir kritis dalam menyelesaikan masalah matematika pada siswa kelas VII SMP Negeri 16 Poleang Tengah ditinjau dari gender. Penelitian ini dilaksanakan di SMP Negeri 16 Poleang Tengah tahun ajaran 2019/2020. Jenis penelitian ini adalah penelitian deskriptif dengan perolehan data menggunakan data kuantitatif dan data kualitatif. Subjek penelitian ini terdiri dari 2 kelas dengan jumlah siswa 40 orang. Teknik analisis data menggunakan analisis deskriptif dan kualitatif yaitu kondensasi data, penyajian data dan penarikan kesimpulan. Hasil penelitian ini adalah siswa laki-laki dengan kemampuan berpikir kritis dalam menyelesaikan masalah matematika diperoleh nilai rata-rata adalah 46,25 sedangkan siswa perempan diperoleh nilai rata-rata sebesar 40,25. Hal ini menunjukkan kemampuan berpikir kritis siswa laki-laki menyelesaikan soal lebih baik dari siswa perempuan. Sedangkan hasil wawancara siswa laki-laki cenderung lebih aktif dalam mengeksplorasi pemahaman yang dimililikinya. Sedangkan siswa perempuan, lebih mengutamakan bagaimana soal terjawab dengan cepat tanpa mengeksplorasi pemahaman yang dimilikinya.
\end{abstract}

Kata Kunci: berpikir kritis, penyelesaian masalah matematika, perbedaan gender.

\section{ANALYSIS OF CRITICAL THINKING ABILITY IN SOLVING MATHEMATICPROBLEMS ASSESSED FROM GENDER IN VII GRADE STUDENTS OF SMP NEGERI 16 POLEANG CENTRAL}

\begin{abstract}
This study aims to determine differences in critical thinking skills in solving math problems in class VII SMP Negeri 16 Poleang Tengah in terms of gender. This research was conducted at SMP Negeri 16 Poleang Tengah in the 2019/2020 school year. This type of research is a descriptive study with data acquisition using quantitative data and qualitative data. The subjects of this study consisted of 2 classes with a total of 40 students. Data analysis techniques used descriptive and qualitative analysis, namely data condensation, data presentation and drawing conclusions. The results of this study were male students with the ability to think critically in solving math problems obtained an average score of 46.25 while female students obtained an average score of 40.25. This shows that male students' critical thinking skills in solving questions are better than female students. Meanwhile, the results of interviews with male students tended to be more active in exploring their understanding. Meanwhile, female students prioritized how questions were answered quickly without exploring their understanding.
\end{abstract}

Keywords: critical thinking, mathematical problem solving, gender differences. 


\section{Pendahuluan}

Pendidikan merupakan suatu sarana yang mampu menciptakan sumber daya manusia yang kritis dan mandiri serta memiliki kualitas yang dapat meningkatkan nilai jual secara menyeluruh, karena pendidikan merupakan modal dasar untuk mendapatkan manusia yang berkualitas. Pendidikan juga merupakan suatu proses yang diperlukan untuk mendapatkan keseimbangan dan kesempurnaan dalam perkembangan individu maupun masyarakat.

Matematika merupakan salah satu ilmu yang mendasari kehidupan manusia. Namun, dalam pelaksanaan pembelajaran matematika tidak terlepas pula dari kendala-kendala yang ada baik itu dari segi guru maupun dari siswa itu sendiri. Seringkali siswa menganggap bahwa matematika adalah pelajaran yang sangat sulit dan menganggap matematika itu tidak penting. Matematika juga disebut sebagai ratunya ilmu (sumber ilmu) mengandung arti bahwa keberadaan matematika tidak bergantung kepada ilmu lain. Oleh karena itu, guru menjadi bagian yang sangat penting dan dibutuhkan oleh siswa.

Mempelajari matematika bukan hanya sekedar untuk mampu berhitung saja, namun lebih dari itu. Dalam mempelajari matematika juga diperlukan cara berpikir dan bernalar agar memperoleh suatu pemikiran yang logis dan teliti dalam memecahkan berbagai permasalahan matematika. Vincent Ruggiero mengartikan berpikir sebagai "segala aktivitas mental yang membantu merumuskan atau memecahkan masalah, membuat keputusan, atau memenuhi keinginan untuk memahami" (Suprayitno, 2018: 31-32).

Hal yang harus diperhatikan dalam pelajaran matematika adalah minat dan kemauan, serta perlunya kemampuan atau skills dalam berpikir tingkat tinggi. Dapat diketahui bahwa kemampuan dalam berpikir tingkat tinggi bukanlah sesuatu yang sederhana melainkan sesuatu yang sangat kompleks dan tentu saja merupakan istilah umum dari berbagai kemampuan berpikir lainnya yang bersifat khusus. Berpikir tingkat tinggi ini misalnya kemampuan dalam berpikir kritis, logis, reflektif, metakognitif dan kreatif.

Berpikir kritis merupakan sebuah proses terarah dan jelas yang digunakan dalam kegiatan mental seperti memecahkan masalah, mengambil keputusan, membujuk, menganalisis asumsi, dan melakukan penelitian ilmiah
(Johnson, 2014: 183). Selain itu, Facione (Steven, 2019: 21) menyatakan bahwa konsep dasar dari berpikir kritis adalah interpretasi, analisis, evaluasi, inferensi, eksplanasi dan regulasi diri. Artinya bahwa dalam mengembangkan kemampuan matematika khususnya kemampuan berpikir kritis, seorang siswa harus memiliki sikap yakin dan percaya akan kemampuan sendiri sahingga terhindar dari rasa cemas dan ragu.

Banyak faktor yang harus diperhatikan dalam mempelajari matematika, antara lain kemauan, kemampuan dan kecerdasan tertentu, kesiapan guru, kesiapan siswa, kurikulum dan metode penyajiannya. Faktor yang tak kalah pentingnya adalah gender. Gender adalah karakteristik laki-laki dan perempuan berdasarkan dimensi sosial budaya yang tampak dari nilai dan tingkah laku. Perbedaan antara laki-laki dan perempuan dalam belajar matematika yaitu laki-laki lebih unggul dalam penalaran, perempuan lebih unggul dalam ketetapan, ketelitian, kecermatan, dan keseksamaan berpikir.

Beberapa penelitian menunjukkan bahwa perempuan lebih labil daripada laki-laki yang pada umumnya stabil. Faktanya, dalam situasi dimana anggota kelompok (laki-laki dan perempuan) perbedaan gender dalam kemampuan matematika dapat dilihat yakni siswa laki-laki lebih bagus dalam perhitungan pengukuran, sains dan olahraga. Sedangkan siswa perempuan lebih bagus dalam perhitungan yang berhubungan dengan tugas-tugas tradisional perempuan, seperti memasak dan menjahit. Hal ini berarti perbedaan gender sangat mempengaruhi prestasi belajar siswa.

Berdasarkan fakta dan informasi yang ada dilapangan peneliti melakukan wawancara terhadap 2 orang siswa dan 1 Guru mata pelajaran matematika kelas VII SMP Negeri 16 Poleang Tengah. Dari siswanya itu sendiri diperoleh fakta bahwa pada umunya mereka kurang tertarik dan merasa bosan dengan pembelajaran yang dilakukan dikelas dikarenakan sejak awal mereka menganggap bahwa mata pelajaran matematika adalah pelajaran yang sangat sulit dan guru juga kurang memberikan variasi dalampembelajaran matematika sehingga siswa mudah bosan dalam mengikuti pembelajaran.

Sedangkan paparan dari guru mata pelajaran matematika kelas VII SMP Negeri 16 
Poleang Tengah, peneliti memperoleh informasi bahwa guru matematika menghadapi masalah sehubungan dengan kegiatan pembelajaran. Hal ini ditemukan beberapa kesulitan diantaranya adanya perbedaan siswa yang memiliki kemampuan tingkat tinggi, sedang dan rendah. Kemudian, dasar pemahaman matematika yang dimiliki oleh siswa tidak kuat, karena kurangnya pemahaman konsep matematika yang diajarkan di $\mathrm{SD}$, sehingga siswa bingung dalam mengikuti pelajaran dan harus diingatkan terlebih dahulu mengenai konsep dasar yang berkaitan dengan materi yang akan diajarkan. Selanjutnya, dalam hal merespon pembelajaran dikelas yaitu kurangnya siswa yang mengajukan atau menjawabpertanyaan yang diberikan oleh guru dan siswa terkesan tidak ada minat untuk mengikuti pembelajaran matematika. Hal ini diketahui dari Kriteria Ketuntasan Minimal (KKM) untuk mata pelajaran matematika adalah 75. Sedangkan siswa yang mencapai KKM itu sekitar 1 atau 2 orang dari jumlah siswa keseluruhan. Akibat dari permasalahan yang didapatkan di SMP Negeri 16 Poleang tengah diduga bahwa kemampuan berpikir kritis siswa kelas VII SMP Negeri 16Poleang Tengah tergolong rendah.

Upaya untuk mengatasi permasalahan di atas yaitu sangat diperlukan usaha guru dalam pembelajaran matematika sehingga dapat diikuti oleh seluruh siswa yang memiliki latar belakang yang berbeda-beda baik antar sesama siswa maupun antara siswa laki-laki dan siswa perempuan dengan adanya minat, kemauan serta keaktifan yang baik dari siswa laki-laki maupun siswa perempuan sehingga mampu meningkatkanhasil belajar siswa dan mampu meningkatkan kemampuan berpikir kritis dalam menyelesaikan masalah matematika antara siswa laki-laki maupun siswa perempuan.

Berdasarkan uraian tersebut, maka perlunya diadakan penelitian untuk mengetahui bagaimana kemampuan berpikir kritis matematis siswa apabila ditinjau dari gender. Oleh karena itu, peneliti tertarik untuk mengadakan penelitian yang berjudul "Analisis Kemampuan Berpikir Kritis dalam Menyelesaikan Masalah Matematika Ditinjau dari Gender pada Siswa Kelas VII SMP Negeri 16 Poleang Tengah".

Berpikir kritis adalah salah satu keterampilan berpikir tingkat tinggi (Thinking Skill). Menurut Nurohman (Junaidi, 2017: 1617) menyatakan bahwa Thingking skill adalah kemampuan seseorang dalam mendayagunakan kemampuan mentalnya untuk menyelesaikan berbagai persoalan dalam kehidupan nyata.Selain itu, Menurut Sumarmo (2017: 96) bahwa berpikir kritis yaitu segala kemampuan diberdayakan, baik itu memahami mengingat, membedakan, menganalisis, memberi alasan, merefleksikan, menafsirkan, mencari hubungan, mengevaluasi bahkan membuat dugaan sementara. Kemudian, menurut (Hidayat, 2018: 2) berpikir kritis merupakan suatu proses menggunakan kemampuan berpikir secara rasional dan reflektif tentang ide atau gagasan yang berhubungan dengan konsep atau masalah yang difokuskan untuk mengambil keputusan tentang apa yang diyakini untuk dilakukan sehingga mampu mencapai suatu tujuan.

Baron (Hendriana, 2017) mengelaborasi indikator berpikir kritis secara rinci sebagai berikut: a) memfokuskan diri pada pertanyaan; b) menganalisis dan menjelaskan pertanyaan, jawaban, dan argumen; c) mempertimbangkan sumber yang tepercaya; d) mendeduksi dan menganalisa deduksi; e) menginduksi dan menganalisa induksi; f) merumuskan penjelasan, hipotesis, dan kesimpulan; g) menyusun pertimbangan yang bernilai ; dan h) berinteraksi dengan yang lain.

Facione menyatakan enam kecakapan berpikir kritis utama yang terlibat di dalam proses berpikir kritis, yaitu: a) Interpretasiadalah memahami dan mengekspresikan makna atau signifikansi dari berbagai macam pengalaman, situasi, data, kejadian-kejadian, penilaian, kebiasaan, atau adat, kepercayaan-kepercayaan, prosedur atau kriteria-kriteria, b) Analisis adalah mengidentifikasi hubungan-hubugan inferensial yang dimaksud dan aktual diantara pernyataanpernyataan, pertanyaan-pertanyaan, konsepkonsep, deskripsi-deskripsi atau bentuk-bentuk representasi lainnya yang dimaksudkan untuk mengekspresikan kepercayaan-kepercayaan, penilaian, pengalaman-pengalaman, alasanalasan, informasi atau opini-opini, c) Evaluasi berarti menaksir kredibilitas pernyataanpernyataan atau representasi-representasi yang merupakan laporan-laporan atau deskripsideskkripsi dari persepsi, pengalaman, situasi, penilaian, kepercayaan atau opini seseorang, dan menaksir kekuatan logis dari hubunganhubungan inferensial atau dimaksud diantara pernyataan-pernyataan, deskripsi-deskripsi, pertanyaan-pertanyaan atau bentuk-bentuk representasi lainnya, d) Inferensi berarti 
mengidentifikasi dan memperoleh unsur-unsur yang diperlukan untuk membuat kesimpulankesimpulan yang masuk akal, membuat dugaandugaan dan hipotesis, mempertimbangkan informasi yang relevan dan menyimpulkan konsekuensi-konsekuensi dari data, situasisituasi, pertanyaan-pertanyaan atau bentukbentukrepresentasi lainnya, e) Eksplanasi dan regulasi diri berarti menjelaskan apa yang mereka pikir dan bagaimana mereka sampai pada kesimpulan yang telah didapat pada saat inferensiKarim dan Normaya (Steven, 2019: 21). Indikator kemapuan berpikir kritis yang dikembangkan Facione (Steven, 2019: 21) diuraikan menjadi beberapa subskill seperti pada Tabel 1 berikut.

Tabel 1

Keterampilan Berpikir Kritis

\begin{tabular}{|c|c|c|}
\hline No. & $\begin{array}{l}\text { Dimensi Kemampuan } \\
\text { Berpikir Kritis }\end{array}$ & Indikator \\
\hline 1. & Interpretasi & $\begin{array}{l}\text { Dapat menggambarkan permasalahan yang } \\
\text { diberikan } \\
\text { Dapat menuliskan permasalahan dengan jelas dan } \\
\text { tepat } \\
\text { Dapat menuliskan apa yang ditanyakan soal dengan } \\
\text { jelas dan tepat }\end{array}$ \\
\hline 2. & Analisis & $\begin{array}{l}\text { Dapat menuliskan hubungan konsep-konsep yang } \\
\text { digunakan dalam menyelesaikan soal } \\
\text { Dapat menuliskan apa yang harus dilakukan dalam } \\
\text { menyelesaikan soal }\end{array}$ \\
\hline 3. & Evaluasi & Dapat menuliskan penyelesaian soal \\
\hline 4. & Inferensi & $\begin{array}{l}\begin{array}{l}\text { Dapat menarik kesimpulan dari apa } \\
\text { ditanyakan secara logis }\end{array} \\
\text { Dapat menduga alternatif lain }\end{array}$ \\
\hline 5. & Eksplanasi & $\begin{array}{l}\text { Dapat menuliskan hasil akhir } \\
\text { Dapat memberikan alasan tentang kesimpulan yang } \\
\text { diambil }\end{array}$ \\
\hline 6. & Regulasi Diri & $\begin{array}{l}\text { Dapat me-review jawaban yang diberikan atau } \\
\text { dituliskan }\end{array}$ \\
\hline
\end{tabular}

Gender berasal dari bahasa latin, yaitu "genus" berarti tipe atau jenis. Gender adalah sifat dan perilaku yang dilekatkan pada laki-laki dan perempuan yang dibentuk secara sosial dan budaya. Hal ini senada dengan Jegtenberg dan D'Alton, " gender and sex are not the same thing. Gender specifically refers to the social meanings attached to biological differences.... The way we see ourselves and the way we interact are affected by our internalization of values and assumptions about gender". Karena dibentuk oleh sosial dan budaya setempat, maka gender tidak berlaku selamanya tergantung pada waktu (tren) dan tempatnya (Amir, 2013: 1617).

Gender adalah perbedaan antara lakilaki dan perempuan yang dibangun secara sosial dan kultural yang berkaitan dengan peran, perilaku, dan sifat yang dianggap layak bagi laki-laki dan perempuan yang dapat dipertukarkan (Masse, 2016: 5).

Menurut Kruteski (Nafi'an, 2011: 573-

574) menyatakan bahwa kemampuan matematika dan mekanika siswa laki-laki lebih baik daripada siswa perempuan. Perbedaan gender bukan hanya berakibat pada perbedaan kemampuan dalam matematika, tetapi cara memperoleh pengetahuan matematika.Siswa pria lebih tertarik dalam pelajaran matematika dibandingkan dengan siswa wanita, sehingga siswa wanita lebih mudah cemas dalam menghadapi matematika dibandingkan dengan siswa pria (Nawangsari, 2008).

Sedangkan para ahli secara umum setuju bahwa hasil belajar yang diakibatkan oleh perbedaan gender adalah hasil bias gender di rumah dan lingkungan sekolah. Hasil penelitian menunjukkan bahwa secara umum, orang tua memiliki harapan lebih besar agar anak laki-laki 
berhasil dalam matematika dan sains dibandingkan anak perempuan mereka. Para orang tua percaya bahwa anak laki-laki memiliki kemampuan yang lebih baik dari pada anak perempuan dalam matematika dan sains, sehingga tidak mengejutkan jika anak laki-laki lebih banyak menempuh pendidikan diilmu fisika dan mesin. Dan memiliki gelar sarjana komputer dan sains informasi, sains fisika dan biologi, permesinan dan matematika (Amir, 2013).

\section{Metode}

Jenis penelitian yang digunakan dalam penelitian ini adalah penelitian deskripti. Penelitian deskriptif memusatkan perhatian kepada masalah-masalah aktual kepada masalah-masalah aktual sebagaimana adanya pada saat penelitian berlangsung. Subjek dalam penelitian ini adalah siswa kelas VII SMP Negeri 16 Poleang Tengah semester genap tahun ajaran 2019/2020 dengan jumlah siswa 40 yang tersebar dalam dua kelas (VII-A dan VII-B).

Instrumen yang digunakan dalam penelitian ini yaitu tes kemampuan berpikir kritis matematis, angket kemampuan berpikir kritis matematis siswa dan wawancara. Tes yang digunakan adalah tes essai berupa soal-soal kemampuan berpikir kritis yang berguna untuk mengukur kemampuan berpikir kritis peserta didik. Angket digunakan untuk mengukur tingkat kemampuan berpikir kritis matematika siswa khususnya pada materi segiempat dan segitiga. Wawancara dilakukan terhadap siswa yang telah ditentukan oleh peneliti sebagai subjek penelitian sesuai dengan kriteria tertentu bertujuan untuk mengetahui lebih lanjut tentang kemampuan berpikir kritis siswa dalam menyelesaikan soal segiempat dan segitiga.

Tekhnik analisis data yang digunakan yaitu:

\section{Analisis Deskriptif}

Analisis deskriptif data penelitian berupa perolehan persentase (\%), mean, median, modus, standar deviasi, varians,range, nilai maksimum dan nilai minimum.

\section{Analisis Data Menurut Miles, Huberman dan Saldana (2014)}

Analisis data menurut Miles, Huberman dan Saldana yaitu: kondensasi data (data condensation), penyajian data (data display), penarikan kesimpulan (conclusions drawing).

Analisis deskriptif juga dimaksudkan untuk mendeskripsikan kemampuan berpikir kritis matematis siswa kelas VII SMP Negeri 16 Poleang Tengah.Data yang dianalisis yaitu data hasil tes dan angket kemampuan berpikir kritis matematis siswa berdasarkan kategori persentase kemampuan berpikir kritis siswa.Nilai persentase kemampuan berpikir kritis dikategorikan sesuai Pedoman Acuan Norma (PAN)

\section{Hasil}

\section{Hasil Analisis Deskriptif}

Hasil analisis deskriptif nilai tes kemampuan berpikir kritis matematis siswa laki-laki dan siswa perempuan kelas VII-A dan kelas VII-B SMP Negeri 16 Poleang Tengah yang diolah dengan menggunakan aplikasi IBM SPSS Statistic dapat dilihat pada Tabel 2.

Tabel 2

Analisis Deskriptif Nilai Tes Kemampuan Berpikir Kritis Siswa Kelas VII-A dan kelas VII-B

\begin{tabular}{ccc}
\hline \multirow{2}{*}{ Statistik Deskriptif } & \multicolumn{2}{c}{ VII-A } \\
\cline { 2 - 3 } & $\mathbf{L}$ & $\mathbf{P}$ \\
\hline $\mathrm{N}$ & 20 & 20 \\
\hline Mean & 46,25 & 40,25 \\
\hline Median & 40 & 37,50 \\
\hline Mode & 35 & 35 \\
\hline Standard Deviation & 18,98 & 13,61 \\
\hline Variasn & 360,20 & 185,46 \\
\hline Range & 60 & 55 \\
\hline Minimum & 20 & 15 \\
\hline Maximum & 80 & 70 \\
\hline
\end{tabular}


Berdasarkan Tabel 2 dapat dilihat bahwa kemampuan berpikir kritis matematis siswa laki-laki dengan jumlah sampel 20 orang, menunjukkan bahwa kemampuan berpikir kritis matematis siswa laki-laki lebih tinggi dibandingkan siswa perempuan. Dan hal ini menunjukkan bahwa kemampuan berpikir kritis matematis siswa laki-laki lebih beragam, dalam arti bahwa kemampuan berpikir kritis siswa laki-laki menyebar lebih jauh dibandingkan dengan siswa perempuan. Dengan kata lain, siswa laki-laki yang memiliki kemampuan tinggi dan siswa laki-laki yang memiliki kemampuan rendah memiliki selisih yang lebih besar dibandingkan dengan siswa perempuan. Serta dilihat dari nilai maximum dan minimum diperoleh kemampuan berpikir kritis laki-laki lebih baik dari pada perempuan.

\section{Analisis Deskriptif Angket Kemampuan Berpikir Kritis}

Hasil analisis deskriptif nilai angket kemampuan berpikir kritis matematis siswa lakilaki dan siswa perempuan kelas VII-A dan kelas VII-B SMP Negeri 16 Poleang Tengah dapat dilihat pada Tabel 3 .

Tabel 3

Analisis Deskriptif Nilai Angket Kemampuan Berpikir Kritis Siswa Kelas VII-A dan kelas VII-B

\begin{tabular}{ccccc}
\hline Statistik Deskriptif & \multicolumn{2}{c}{ VII-A } & \multicolumn{2}{c}{ VII-B } \\
\cline { 2 - 5 } & L & P & L & P \\
\hline $\mathrm{N}$ & 10 & 10 & 10 & 10 \\
\hline Mean & 58,43 & 50,57 & 62,12 & 64,29 \\
\hline Median & 57,95 & 46,02 & 62,50 & 60,80 \\
\hline Mode & 35 & 45,45 & 79,55 & 40,91 \\
\hline Standard Deviation & 15,97 & 10,92 & 15,78 & 14,19 \\
\hline Variasn & 255,13 & 119,16 & 249,01 & 201,55 \\
\hline Range & 35,68 & 30,68 & 40,91 & 46,59 \\
\hline Minimum & 35 & 39,77 & 38,64 & 40,91 \\
\hline Maximu & 80,68 & 70,45 & 79,55 & 87,50 \\
\hline
\end{tabular}

Berdasarkan Tabel 3 dapat di lihat bahwa hasil angket kemampuan berpikir kritis pada kelas VII-A, siswa laki-laki dengan jumlah sampel 10 orang, diperoleh rata-rata sebesar 58,43, median sebesar 57,95 dan modus sebesar. Sedangkan siswa perempuan dengan jumlah sampel 10 orang, diperoleh rata-rata sebesar 50,57, median sebesar 46,02 dan modus sebesar 45,45 . Hal ini menunjukkan bahwa kemampuan berpikir kritis matematis siswa laki-laki lebih tinggi dibandingkan siswa perempuan. Selain itu, pada siswa laki-laki diperoleh standar deviasi sebesar 15,97 dan varians sebesar 255,13 . Sedangkan pada siswa perempuan diperoleh standar deviasi sebesar 10,92 dan varians sebesar 119,16. Hal ini menunjukkan bahwa kemampuan berpikir kritis matematis siswa laki-laki lebih beragam, dalam arti bahwa kemampuan berpikir kritis siswa laki-laki menyebar lebih jauh dibandingkan dengan siswa perempuan. Dengan kata lain, siswa laki-laki yang memiliki kemampuan tinggi dan siswa laki-laki yang memiliki kemampuan rendah memiliki selisih yang lebih besar dibandingkan dengan siswa perempuan. Selain itu pada siswa laki-laki, diperoleh range sebesar 35,68; minimum sebesar 35 dan maksimum sebesar 80,68 . Sedangkan pada siswa perempuan diperoleh range sebesar 30,68, minimum sebesar 39,77 dan maksimum sebesar 70,45.

Sedangkan hasil angket kemampuan berpikir kritis matematis kelas VII-B, pada siswa laki-laki dengan jumlah sampel 10 orang diperoleh rata-rata sebesar 62,12; median sebesar 62,50 dan modus sebesar 79,55. Sedangkan pada siswa perempuan dengan jumlah sampel 10 orang, diperoleh rata-rata sebesar 64,29; median sebesar 60,80 dan modus sebesar 40,91. Hal ini menunjukkan bahwa kemampuan berpikir kritis matematis siswa lakilaki lebih tinggi dibandingkan siswa perempuan. Pada siswa laki-laki juga diperoleh standar deviasisebesar 15,78 dan varians sebesar 249,01. Sedangkan pada siswa perempuan 
diperoleh standar deviasi sebesar 14,19 dan varians sebesar 201,55. Hal ini menunjukkan bahwa kemampuan berpikir kritis matematis siswa laki-laki lebih beragam, dalam arti bahwa kemampuan berpikir kritis siswa laki-laki menyebar lebih jauh dibandingkan dengan siswa perempuan. Dengan kata lain, siswa laki-laki yang memiliki kemampuan tinggi dan siswa laki-laki yang memiliki kemampuan rendah memiliki selisih yang lebih besar dibandingkan dengan siswa perempuan. Selain itu, pada siswa laki-laki diperoleh range sebesar 40,91; minimum sebsar 38,64 dan sebesar 79,55. Sedangkan pada siswa perempuan diperoleh range sebesar 46,59; minimum sebesar 40,91 dan maksimum sebesar 87,50.

\section{Analisis Deskripsi Perindikator Berpikir Kritis}

Hasil deskriptif perindikator kemampuan berpikir kritis matematis siswa lakilaki dan siswa perempuan kelas VII SMP Negeri 16 Poleang Tengah dapat di lihat pada Tabel 4.

Tabel 4

Analisis Deskriptif perindikator Kemampuan Berpikir Kritis Siswa Laki-Laki dan Perempuan Kelas VII

\begin{tabular}{|c|c|c|c|c|c|}
\hline \multirow{2}{*}{$\begin{array}{c}\text { No. } \\
\text { Soal }\end{array}$} & \multirow{2}{*}{$\begin{array}{c}\text { Indikator } \\
\text { Berpikir } \\
\text { Kritis }\end{array}$} & \multicolumn{2}{|c|}{ Laki-Laki } & \multicolumn{2}{|c|}{ Perempuan } \\
\hline & & Frekuensi & Persentase (\%) & Frekuensi & Persentase (\%) \\
\hline \multirow[t]{6}{*}{1} & Interpretasi & 6 & 30 & 5 & 25 \\
\hline & Analisis & 11 & 55 & 12 & 60 \\
\hline & Evaluasi & 9 & 45 & 6 & 30 \\
\hline & Inferensi & 4 & 20 & 3 & 15 \\
\hline & Eksplanasi & 5 & 25 & 4 & 20 \\
\hline & Regulasi diri & 12 & 60 & 10 & 50 \\
\hline \multirow[t]{6}{*}{2} & Interpretasi & 7 & 35 & 5 & 25 \\
\hline & Analisis & 12 & 60 & 11 & 55 \\
\hline & Evaluasi & 7 & 35 & 4 & 20 \\
\hline & Inferensi & 5 & 25 & 2 & 10 \\
\hline & Eksplanasi & 2 & 10 & - & - \\
\hline & Regulasi diri & 12 & 60 & 10 & 50 \\
\hline \multirow[t]{6}{*}{3} & Interpretasi & 3 & 15 & 2 & 10 \\
\hline & Analisis & 3 & 15 & 2 & 10 \\
\hline & Evaluasi & 3 & 15 & 2 & 10 \\
\hline & Inferensi & 4 & 20 & 2 & 10 \\
\hline & Eksplanasi & 2 & 10 & - & - \\
\hline & Regulasi diri & 12 & 60 & 10 & 50 \\
\hline \multirow[t]{6}{*}{4} & Interpretasi & 6 & 30 & 4 & 20 \\
\hline & Analisis & 7 & 35 & 7 & 35 \\
\hline & Evaluasi & 6 & 30 & 4 & 20 \\
\hline & Inferensi & 6 & 30 & 4 & 20 \\
\hline & Eksplanasi & 6 & 30 & 4 & 20 \\
\hline & Regulasi diri & 12 & 60 & 10 & 50 \\
\hline \multirow[t]{6}{*}{5} & Interpretasi & 6 & 30 & 7 & 35 \\
\hline & Analisis & 9 & 45 & 10 & 50 \\
\hline & Evaluasi & 6 & 30 & 5 & 25 \\
\hline & Inferensi & 6 & 30 & 6 & 30 \\
\hline & Eksplanasi & 6 & 30 & 5 & 25 \\
\hline & Regulasi diri & 12 & 60 & 10 & 50 \\
\hline
\end{tabular}

Berdasarkan Tabel 4 dapat di lihat bahwa hasil analisis deskriptif perindikator kemampuan berpikir kritis siswa laki-laki dengan sampel 20 orang. Pada soal nomor 1, 
indikator interpretasi memiliki frekuensi yang menjawab benar ada 6 orang dengan persentase sebesar $30 \%$. Indikator analisis memiliki frekuensi 11 dengan persentase 55\%. Indikator evaluasi memiliki frekuensi 9 dengan persentase sebesar $45 \%$. Indikator inferensi memiliki frekuensi 4 dengan persentase $20 \%$. Indikator eksplanasi memiliki frekuensi 5 dengan persentase $25 \%$ dan indikator regulasi diri memiliki frekuensi 12 dengan persentase sebesar $60 \%$. Pada soal nomor 2, indikator interpretasi memiliki frekuensi 7 dengan persentase sebesar $35 \%$. Indikator analisis memiliki frekuensi 12 dengan persentase $60 \%$. Indikator evaluasi memiliki frekuensi 7 dengan persentase sebesar $35 \%$. Indikator inferensi memiliki frekuensi 5 dengan persentase sebesar $25 \%$ Indikator eksplanasi memiliki frekuensi 2 dengan persentase $10 \%$ dan indikator regulasi diri memiliki frekuensi 12 dengan persentase sebesar $60 \%$. Pada soal nomor 3, indikator interpretasi, analisis, evaluasi memiliki frekuensi yang sama yaitu 3 dengan persentase sebesar $15 \%$. Indikator inferensi memiliki frekuensi 4 dengan persentase sebesar 20\%. Indikator eksplanasi memiliki frekuensi 2 dengan persentase sebesar $10 \%$ dan regulasi diri memiliki frekuensi 12 dengan persentase sebesar $60 \%$. Pada soal nomor 4, indikator interpretasi memiliki frekuensi 6 dengan persentase sebesar 30\%. Indikator analisis memiliki frekuensi 7 dengan persentase sebesar $35 \%$. Indikator evaluasi, inferensi, ekplanasi memiliki frekuensi yang sama dengan persentase sebesar 30\% dan indicator regulasi diri memiliki frekuensi sebesar 12 dengan persentase sebesar $60 \%$. Pada soal nomor 5, indikator interpretasi memiliki frekuensi 6 dengan persentase sebesar $30 \%$. Indikator analisis memiliki frekuensi 9 dengan persentase sebesar $45 \%$. Indikator evaluasi, inferensi, ekplanasi memiliki frekuensi yang sama yaitu 6 dengan persentase sebesar 30\% dan indikator regulasi diri memiliki frekuensi 12 dengan persentase sebesar $60 \%$.

Sedangkan hasil analisis deskriptif perindikator kemampuan berpikir kritis siswa perempuan dengan jumlah sampel 20 orang. Pada soal nomor 1, indikator interpretasi memiliki frekuensi sebesar 5 dengan persentase sebesar $25 \%$. Indikator analisis memiliki frekuensi 5 dengan persentase sebesar $60 \%$. Indikator evaluasi memiliki frekuensi sebesar 12 dengan persentase sebesar $30 \%$. Indikator inferensi memiliki frekuensi 6 dengan persentase sebesar $15 \%$. Indikator eksplanasi memiliki frekuensi 4 dengan persentase sebesar $20 \%$ dan indikator regulasi diri memiliki frekuensi 10 dengan persentase sebesar $50 \%$. Pada soal nomor 2, indikator interpretasi memiliki frekuensi 5 dengan persentase sebesar $25 \%$. Indikator analisis memiliki frekuensi 11 dengan persentase sebesar 55\%. Indikator evaluasi memiliki frekuensi sebesar 4 dengan persentase sebesar 20\%. Indikator inferensi memiliki frekuensi 5 dengan persentase sebesar $10 \%$. Indikator regulasi diri memiliki frekuensi 10 dengan persentase sebesar 50. Pada soal nomor 3, indikator interpretasi, analisis, evaluasi, inferensi memiliki frekuensi yang sama yaitu 2 dengan persentase sebesar $10 \%$ dan indikator regulasi diri memiliki frekuensi 10 dengan persentase sebesar 50\%. Pada soal nomor 4, indikator interpretasi memiliki frekuensi 4 dengan persentase sebesar $20 \%$. Indikator analisis memiliki frekuensi 7 dengan persentase sebesar 30\%. Indikator evaluasi, inferensi, eksplanasi memiliki frekuensi yang sama yaitu 4 dengan persentase sebesar $20 \%$ dan indikator regulasi diri memiliki frekuensi 10 dengan persentase sebesar $50 \%$. Pada soal nomor 5, indikator interpretasi memiliki frekuensi 7 dengan persentase sebesar 35\%. Indikator analisis memiliki frekuensi 10 dengan persentase sebesar 50\%. Indikator evaluasi dan ekplanasi memiliki frekuensi yang sama yaitu 5 dengan persentase sebesar $25 \%$. Indikator inferensi memiliki frekuensi 6 dengan persentase sebesar 30 dan indikator regulasi diri memiliki frekuensi 10 dengan persentase sebesar $50 \%$.

Berdasarkan uraian di atas, terlihat bahwa hasil dari analisis perindikator kemampuan berpikir kritis siswa kelas VII SMP Negeri 16 Poleang Tengah ditinjau dari gender diperoleh bahwa siswa laki-laki lebih baik dibandingakan dengan siswa perempuan. Hal ini terlihat kemampuan siswa laki-laki pada tiap soal hampir mampu melakukan semua indikator kemampuan berpikir kritis sedangkan pada siswa perempuan ada beberapa indikator yang tidak dilakukan.

\section{Pengelompokkan Tes dan Angket Kemampuan Berpikir Kritis Siswa}


Pengelompokkan Tes Kemampuan Berpikir Kritis Siswa Kelas VII dalam Menyelesaikan Masalah Matematika

Pengelompokkan kemampuan berpikir kritis siswa dalam menyelesaikan masalah matematika didasarkan pada pedoman acuan norma (PAN) dalam lima kategori, yaitu sangat tinggi, tinggi, sedang, rendah dan sangat rendah yang disajikan pada Tabel 5 dan Tabel 6 berikut

Tabel 5

Daftar Nilai Tes dan Pengelompokkan Kemampuan Berpikir Kritis Matematis Siswa Kelas VII-A

\begin{tabular}{ccccc}
\hline No & Interval & Kategori & Total Siswa & Persentase (\%) \\
\hline 1 & $90<$ Nilai $\leq 100$ & Sangat Tinggi & - & - \\
\hline 2 & $75<$ Nilai $\leq 90$ & Tinggi & 2 & 10 \\
\hline 3 & $60<$ Nilai $\leq 75$ & Sedang & 1 & 5 \\
\hline 4 & $40<$ Nilai $\leq 60$ & Rendah & 4 & 20 \\
\hline 5 & $0<$ Nilai $\leq 40$ & Sangat Rendah & 14 & 70 \\
\hline
\end{tabular}

Berdasarkan Tabel 5 bahwa kategori kemampuan berpikir kritis sangat tinggi dengan interval $90<$ Nilai $\leq 100$ memiliki frekuensi 0 dengan persentase sebesar $0 \%$. Kategori kemampuan berpikir kritis tinggi dengan interval $75<$ Nilai $\leq 90$ memiliki frekuensi 2 dengan persentase sebesar $10 \%$. Kategori kemampuan berpikir kritis sedang dengan interval $60<$ Nilai $\leq 75$ memiliki frekuensi 1 dengan persentase sebesar 5\%. Kategori kemampuan berpikir kritis rendah dengan interval $40<$ Nilai $\leq 60$ memiliki frekuensi 4 dengan persentase sebesar20\%dan kategori kemampuan berpikir kritis sangat rendah dengan interval $0<$ Nilai $\leq 40$ memiliki frekuensi 14 dengan persentase sebesar 70 .

Tabel 6

Daftar Nilai Tes dan Pengelompokkan Kemampuan Berpikir Kritis Matematis Siswa Kelas VII-B

\begin{tabular}{ccccc}
\hline No & Interval & Kategori & Total Siswa & Persentase (\%) \\
\hline 1 & $90<$ Nilai $\leq 100$ & Sangat Tinggi & - & - \\
\hline 2 & $75<$ Nilai $\leq 90$ & Tinggi & 1 & 5 \\
\hline 3 & $60<$ Nilai $\leq 75$ & Sedang & 1 & 5 \\
\hline 4 & $40<$ Nilai $\leq 60$ & Rendah & 5 & 25 \\
\hline 5 & $0<$ Nilai $\leq 40$ & Sangat Rendah & 15 & 75 \\
\hline
\end{tabular}

Berdasarkan Tabel 6 bahwa kategori kemampuan berpikir kritis sangat tinggi dengan interval $90<$ Nilai $\leq 100$ memiliki frekuensi 0 dengan persentase sebesar 0\%.Kategori kemampuan berpikir kritis tinggi dengan interval $75<$ Nilai $\leq 90$ memiliki frekuensi 1 dengan persentase sebesar 5\%. Kategori kemampuan berpikir kritis sedang dengan interval $60<$ Nilai $\leq 75$ memiliki frekuensi 1 dengan persentase sebesar $5 \%$. Kategori kemampuan berpikir kritis rendah dengan interval $40<$ Nilai $\leq 60$ memiliki frekuensi 5 dengan persentase sebesar $25 \%$ dan kategori kemampuan berpikir kritis sangat rendah dengan interval $0<$ Nilai $\leq 40$ memiliki frekuensi 15 dengan persentase sebesar $70 \%$.
Pengelompokkan Angket Kemampuan Berpikir Kritis Siswa Kelas VII SMP Negeri 16 Poleang Tengah
Pengelompokkan kemampuan berpikir kritis siswa didasarkan pada pedoman acuan norma (PAN) dalam lima kategori, yaitu sangat tinggi, tinggi, sedang, rendah dan sangat rendah yang disajikan pada Tabel 7 dan Tabel 8 berikut. 
Tabel 7

Daftar Nilai Angket dan Pengelompokkan Kemampuan Berpikir Kritis Matematis Siswa Kelas VII-A

\begin{tabular}{ccccc}
\hline No & Interval & Kategori & Frekuensi & Persentase (\%) \\
\hline 1 & $90<$ Nilai $\leq 100$ & Sangat Tinggi & - & - \\
\hline 2 & $75<$ Nilai $\leq 90$ & Tinggi & 2 & 10 \\
\hline 3 & $60<$ Nilai $\leq 75$ & Sedang & 6 & 30 \\
\hline 4 & $40<$ Nilai $\leq 60$ & Rendah & 12 & 60 \\
\hline 5 & $0<$ Nilai $\leq 40$ & Sangat Rendah & 1 & 5 \\
\hline
\end{tabular}

Berdasarkan Tabel 7 menunjukkan bahwa hasil angket kategori kemampuan berpikir kritis tinggi dengan interval $75<$ Nilai $\leq 90$ memiliki frekuensi 2 dengan persentase sebesar $10 \%$. Kategori kemampuan berpikir kritis sedang dengan interval $60<$ Nilai $\leq 75$ memiliki frekuensi 6 dengan persentase sebesar

30\%. Kategori kemampuan berpikir kritis rendah dengan interval $40<$ Nilai $\leq 60$ memiliki frekuensi 12 dengan persentase sebesar $60 \%$. Sedangkan kategori sangat rendah $0<$ Nilai $\leq 40$ memiliki frekuesi 1 dengan persentase sebesar $5 \%$.

Table 8

Daftar Nilai Angket dan Pengelompokkan Kemampuan Berpikir Kritis Matematis Siswa Kelas VII-B

\begin{tabular}{ccccc}
\hline No & Interval & Kategori & Frekuensi & Persentase (\%) \\
\hline 1 & $90<$ Nilai $\leq 100$ & Sangat Tinggi & - & - \\
\hline 2 & $75<$ Nilai $\leq 90$ & Tinggi & 7 & 35 \\
\hline 3 & $60<$ Nilai $\leq 75$ & Sedang & 4 & 20 \\
\hline 4 & $40<$ Nilai $\leq 60$ & Rendah & 10 & 50 \\
\hline 5 & $0<$ Nilai $\leq 40$ & Sangat Rendah & 1 & 5 \\
\hline
\end{tabular}

Berdasarkan Tabel 8 menunjukkan bahwa hasil angket kategori kemampuan berpikir kritis tinggi dengan interval $75<$ Nilai $\leq 90$ memiliki frekuensi 7 dengan persentase sebesar 35\%. Kategori kemampuan berpikir kritis sedang dengan interval $60<$ Nilai $\leq 75$ memiliki frekuensi 4 dengan persentase sebesar $20 \%$. Kategori kemampuan berpikir kritis rendah dengan interval $40<$ Nilai $\leq 60$ memiliki frekuensi 10 dengan persentase sebesar $50 \%$. Sedangkan kategori kemampuan berpikir kritis sangat rendah $0<$ Nilai $\leq 40$ memiliki frekuesi 1 dengan persentase sebesar $5 \%$.

\section{Hasil Tes Tertulis Dilengakapi dengan Wawancara}

Selain analisis hasil tes siswa, peneliti juga melalukan analisis wawancara dengan subjek penelitian. Hal ini bertujuan untuk mengkonfirmasi ulang proses yang dilakukan subjek penelitian untuk menyelesaikan soal tes kemampuan berpikir kritis yang diberikan. Selain itu, untuk mengetahui lebih lanjut terkait cara atau pola berpikir subjek terhadap kemampuan berpikir kritis dari soal tes yang diberikan.

Adapun data lengkap (data tes tertulis dilengkapi dengan wawancara) adalah sebagai berikut.

Deskripsi hasil analisis jawaban subjek B10 berjenis kelamin laki-laki dengan nilai tes kemampuan berpikir kritis kategori sedang

$$
\begin{aligned}
& \text { 3) diketatiul: } \\
& A B=20 \mathrm{~cm} \\
& B C=166 \mathrm{~m} \\
& A D=126 \mathrm{~m} \\
& \text { dibanya } \\
& \text { tinggi CE? } \\
& \text { Jawab: } \\
& \frac{1}{2} \times B C \times A O=\frac{1}{2} \times A B \times C E \\
& 16 \mathrm{~cm} \times 12 \mathrm{Cm}=20 \times \mathrm{CE} \\
& 192 \mathrm{~cm}^{2}=20 \times[E \\
& C E=\frac{192}{20} \\
& =9,6 \mathrm{Cm}
\end{aligned}
$$

Gambar 1. Jawaban subjek B10 
Berdasarkan hasil tes peneliti melakukan wawancara pada subjek B10 yang berjenis kelamin laki-laki untuk menindak lanjuti kemampuan berpikir kritis siswa tersebut. Peneliti mengajukan pertanyaan pertama yaitu apa yang kamu pahami dari soal?. subjek mengemukakan bahwa "karena dari soal sudah ada yang diketahui dan ditanyakan jadi saya menggunakan rumus tersebut. Nah dari rumus tersebut kita bisa menyelesaikan permasalahan pada soal". Peneliti melanjutkan wawancara dengan mengajukan pertanyaan kedua yaitu lalu bagaimana cara melesaikannya sehingga diperoleh hasil akhir seperti yang telah kamu tuliskan?. Subjek mengemukakan bahwa "saya langsung memasukkan nilai yang telah diketahui sesuai kebutuhan rumus. Sehingga saya mengerjakan sesuai langkah-langkah penyelesaian soal dan saya memperoleh hasil akhir 9,6 cm'.Peneliti mengajukan lagi pertanyaan ketiga yaitu kenapa kamu tidak tuliskan kesimpulan dari hasil akhir yang diperoleh? dan apakah diperiksa kembali jawaban sebelum dikumpulkan?. Subjek mengemukakan lagi bahwa ' 'maaf kak. Saya lupa untuk menuliskan kesimpulannya. Saya memeriksa kembali sebelum saya kumpul lembar jawaban'.

Dari hasil tes dan wawancara dapat disimpulkan bahwa subjek B10 berjenis kelamin laki-laki mampu melakukan beberapa indikator kemampuan berpikir kritis diantaranya indikator interpretasi (subjek dapat menuliskan permasalahan pada soal dan subjek dapat menuliskan yang ditanyakan pada soal), indikator analisis (subjek dapat menuliskan konsep yang diguanakan untuk menyelesaikan soal), indikator evaluasi ( subjek dapat menyelesaikan soal tersebut dengan menggunakan konsep dengan benar), indikator inferensi (subjek dapat menuliskan hasil akhir dengan benar) dan regulasi diri (subjek melakaukan pengecekan kembali pada lembar jawaban yang telah dituliskan). Sedangkan indikator yang tidak dilakukan oleh subjek yaitu indikator eksplanasi (subjek tidak menuliskan kesimpulan dari hasil akhir yang diperoleh). Sehingga subjek tersebut termasuk kategori sedang.

Deskripsi hasil analisis jawaban subjek A05 berjenis kelamin perempuan dengan nilai tes kemampuan berpikir kritis kategori sedang

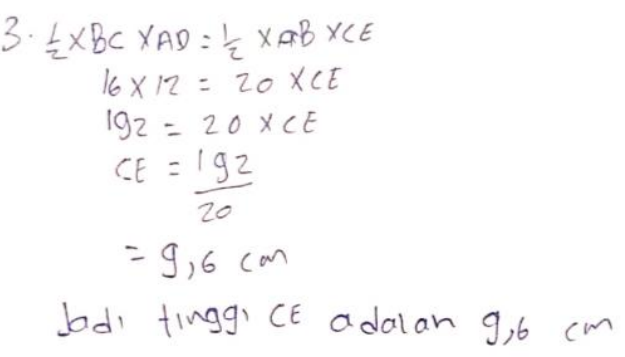

\section{Gambar 2. Jawaban subjek A05}

Berdasarkan hasil tes peneliti melakukan wawancara pada subjek A05 yang berjenis kelamin perempuan untuk menindak lanjuti kemampuan berpikir kritis siswa tersebut. Peneliti mengajukan pertanyaan pertama yaitu apa yang kamu pahami dari soal?. subjek mengemukakan bahwa "saya melihat dari soal sudah ada yang diketahui. Jadi saya langsung mengerjakan dengan menuliskan rumus tersebut seperti yang telah saya tuliskan". Selanjutnya Peneliti mengajukan lagi pertanyaan kedua yaitu kenapa kamu tidak tuliskan pada lembar jawaban yang diketahui dan ditanyakan dari soal?. Subjek langsung menjawab bahwa " saya tidak menuliskan kak karena biasanya saya langsung menyelesaikan soal jika saya sudah mengetahui rumus yang akan saya gunakan untuk menyelesaikan soal'. Peneliti melanjutkan wawancara dengan mengajukan pertanyaan ketiga yaitu lalu bagaimana kamu bisa menyelesaikan. Coba jelaskan kembali jawaban yang telah dituliskan? Subjek mengemukakan bahwa ''ini kan sudah ada diketahui dari soal. Jadi dengan rumus ini kita bisa menyelesaiakannya dengan memasukkan nilai yang sudah ada. Jadi saya bisa peroleh nilai 9,6 cm. sehingga nilai dari tinggi $C E$ adalah 9,6 cm'. Peneliti mengemukakan pertanyaan terakhir apakah kamu memeriksa kembali jawaban yang telah kamu tuliskan?. Subjek pun menjawab bahwa "saya tidak periksa kak. Saya buru-buru karena waktu tinggal sedikit'”.

Dari hasil tes dan wawancara dapat disimpulkan bahwa subjek A05 berjenis kelamin perempuan hanya mampu melakukan beberapa indikator diantaranya: indikator analisis (subjek dapat menuliskan konsep dengan benar untuk menyelesaikan soal tersebut), indikator evaluasi (subjek dapat menuliskan penyelesaian soal sesuai langkah-langkah penyelesaian dengan benar), indikaor inferensi dan indikaor eksplanasi (subjek dapat menuliskan kesimpulan 
dari hasil akhir yang diperoleh) . sedangkan indikator yang tidak dilakukan oleh subjek yaitu indikator interpretasi (subjek tidak menuliskan permasalahan pada soal dan tidak menuliskan yang ditanyakan pada soal) dan indikaor regulasi diri (subjek tidak melakukan pengecekan kembali pada lembar jawaban). Sehingga subjek perempuan tersebut masih dikategorikan sebagai kemampuan berpikir kritis sedang..

Berdasarkan hasil pembahasan yang telah dipaparkan, Maka hasil yang diperoleh memiliki kesesuaian dengan kajian teori BAB II. Teori perbedaan gender menurut Krutetski (Nafi'an, 2011: 573-574) menyatakan bahwa kemampuan matematika dan mekanika siswa laki-laki lebih baik daripada siswa perempuan. Sejalan dengan teori tersebut, berdasarkan hasil analisis diperoleh bahwa siswa laki-laki cenderung lebih aktif dalam mengeksprolasi pemahaman yang dimilikinya. Hal ini terlihat pada hasil wawancara subjek laki-laki lebih aktif dalam memberikan pemahaman mereka. Berbeda halnya dengan perempuan lebih mengutamakan bagaimana soal tersebut bisa terjawab dengan cepat tanpa mengekspor pemahaman yang dimilikinya. Hal ini berdasarkan hasil wawancara subjek perempuan kebanyakan hanya menuliskan jawaban dan tidak memahami makna dari soal. Selain itu, teori lain menurut Elliot (De Carvalho, 2017: 52-53) menyatakan bahwa kemampuan verbal siswa perempuan lebih baik dibandingkan dengan siswa laki-laki yang berarti bahwa kemampuan memahami masalah siswa perempuan lebih tinggi dibandingkan dengan siswa laki-laki. Namun, pada kenyataannya diperoleh bahwa kemampuan matematika siswa laki-laki lebih tinggi dibandingkan dengan siswa perempuan. Hal ini juga didasari oleh teori yang menyatakan bahwa laki-laki lebih baik dalam ketetapan, ketelitian, kecermatan, dan keseksamaan berpikir. Sehingga, dalam menyelesaikan soal matematika siswa laki-laki lebih baik dalam menggunakan rumus dan apa saja yang dibutuhkan dalam menyelesaikan soal yang diberikan.

\section{Pembahasan}

Berdasarkan hasil penelitian terdapat beberapa temuan penelitian seperti yang sudah dijelaskan sebelumnya, dari paparan sebelumnya dapat diketahui bahwa penelitian mengenai kemampuan berpikir kritis siswa dalam menyelesaikan masalah matematika ditinjau dari perbedaan gender pada siswa kelas VII SMP Negeri 16 Poleang Tengah, ada beberapa siswa yang memenuhi indikator kemampuan berpikir kritis menurut Facione, walaupun ada juga yang hanya mampu memenuhi beberapa indikator kemampuan berpikir kritis menurut Facione. Pada penelitian ini, peneliti menggunakan teori Facione yang dikemukakan oleh Steven mengenai kemampuan berpikir kritis, berikut merupakan pedoman yang digunakan sebagai analisis jawaban siswa: (1) inteprestasi (menuliskan yang didiketahui dan ditanyakan pada soal), (2) analisis (menuliskan konsep yang diguanakan dalam menyelesaikan soal, (3) evaluasi (menguraikan jawaban), (4) inferensi (menuliskan hasil akhir), (5) eksplanasi

(menuliskan kesimpulan dari hasil yang diperoleh), (6) regulasi diri (me-review jawaban yang dituliskan). Selain itu, Peneliti masih menemukan siswa yang belum mampu menyelesaikan permasalahan yang berkaitan dengan materi segiempat dan segitiga. Hal ini didasarkan pada hasil tes dan wawancara yang telah dilakukan oleh peneliti kepada siswa yang terpilih sebagai subjek penelitian. Melihat hasil tes dan wawancara yang paling sering ditemukan yaitu bahwa masih banyak siswa yang kurang mampu membuat kesimpulan dari hasil permasalahan dan kurang mampu menentukan alternative atau konsep dalam menyelesaikan permasalahan. Hal ini sejalan dengan pendapat Muliana yang mengatakan dari hasil penelitian yang dilakukan diketahui hampir semua siswa tidak dapat menyimpulkan dari permasalahan. Hal ini menyebabkan siswa tidak dapat menyelesaikan masalah yang diberikan.

Berdasarkan hasil analisis deskriptif dari data hasil tes yang telah diperoleh, hasil rata-rata dan nilai maksimum kelas VII-A yaitu 46,25 dan 80 dengan jumlah siswa sebanyak 20 orang. Pada kelas VII-B nilai rata-rata dan nilai maksimum yaitu 40,25 dan 75 dengan jumlah siswa 20 orang. Berdasarkan nilai rata-rata dan nilai maksimum maka kemampuan berpikir kritis siswa kelas VII-A lebih baik dari pada siswa kelas VII-B. Selain itu, dapat juga kita lihat bahwa hasil nilai rata-rata, nilai minimum dan nilai maksimum laki-laki dengan jumlah siswa 20 orang yaitu 46,$25 ; 20$, dan 80 . Sedangkan hasil nilai rata-rata, nilai minimum dan nilai maksimum perempuan dengan jumlah 
siswa 20 orang pada yaitu 40,25; 15 dan 70 . Berdasarkan nilai rata-rata, minimum dan maksimum maka kemampuan berpikir kritis siswa laki-laki lebih baik dibandingkan dengan siswa perempuan.

\section{Simpulan dan Saran}

\section{Simpulan}

Berdasarkan hasil pembahasan dan analisis data yang telah dilakukan serta sesuai rumusan masalah yang ada, maka dapat dikemukakan beberapa kesimpulan sebagai berikut :

Berdasarkan hasil pembahasan dan analisis data yang telah dilakukan serta sesuai rumusan masalah yang ada, maka dapat dikemukakan beberapa kesimpulan sebagai berikut :

1. Kemampuan berpikir kritis dalam menyelesaikan masalah matematika pada kelas VII SMP Negeri 16 Poleang Tengah khusunya materi Segiempat dan Segitiga. Secara deskriptif kemampuan berpikir kritis dalam menyelesaikan masalah matematika Pada kelas VII-A diperoleh rata-rata sebesar 46,25 Sedangkan pada kelas VII-B diperoleh nilai rata-rata sebesar 40,25. Hal ini menunjukkan bahwa kemampuan berpikir kritis siwa kelas VIIA lebih tinggi dibandingkan dengan kemampuan berpikir kritis siswa Kelas VII-B.

2. Perbedaan kemampuan berpikir kritis dalam menyelesaikan masalah matematika ditinjau dari gender pada siswa kelas VII SMP Negeri 16 Poleang Tengah bahwa siswa laki-laki diperoleh nilai rata-rata sebesar 46,25. Sedangkan siswa perempuan diperoleh nilai rata-rata sebesar 40,25. Hal ini terlihat bahwa kemampuan berpikir kritis dalam menyelesaikan masalah matematika khususnya materi segiempat dan segitiga, siswa laki-laki lebih baik dari pada siswa perempuan.

3. Berdasarkan hasil wawancara siswa lakilaki cenderung lebih aktif dalam mengeksplorasi pemahaman yang dimilikinya untuk dapat menyelesaikan soal matematika khususnya materi Segiempat dan Segitiga. Hal ini terlihat dari subjek laki-laki yang di analisis, menunjukkan bahwa siswa laki-laki mampu menyebutkan informasi terkait masalah dalam soal sehingga dapat mempermudah dalam mengerjakan soal yang ada. Sedangkan siswa perempuan, lebih mengutamakan bagaimana agar soal dapat terjawab dengan cepat dan tepat, tanpa mengeksplorasi pemahaman yang dimilikinya, sehingga siswa perempuan tidak memiliki sudut pandang yang berbeda dalam menyelesaikan soal yang di berikan. Selain itu, siswa laki-laki memiliki daya abstraksi yang baik, sehingga dapat lebih mudah mengekplorasi pemahaman yang dimiliki untuk menyelesaikan soal segiempat dan segitiga, dan siswa laki-laki memiliki daya kritis yang baik dalam menyelesaikan soal yang ada. Berbeda halnya dengan siswa perempuan, di mana siswa perempuan daya kritisnya kurang dalam penyelesaian soal segiempat dan segitiga.

4. Hasil analisis perindikator kemampuan berpikir kritis siswa laki-laki pada indikator interprestasi diperoleh rata-rata persentase sebesar $28 \%$, analisis diperoleh rata-rata persentase sebesar $42 \%$, evaluasi diperoleh rata-rata persentase sebesar $31 \%$, inferensi diperoleh rata-rata persentase sebesar $25 \%$, eksplanasi diperoleh rata-rata persentase sebesar $21 \%$, regulasi diri diperoleh ratarata persentase sebesar 6\%. Sedangkan siswa perempuan pada indikator interprestasi diperoleh rata-rata persentase sebesar $23 \%$, analisis diperoleh rata-rata persentase sebesar $42 \%$, evaluasi diperoleh rata-rata persentase sebesar $21 \%$, inferensi diperoleh rata-rata persentase sebesar $17 \%$, eksplanasi diperoleh rata-rata persentase sebesar $13 \%$, regulasi diri diperoleh ratarata persentase sebesar 5\%. Hal ini menunjukkan bahwa kemampuan berpikir kritis siswa laki-laki lebih baik daripada siswa perempuan.

\section{Saran}

Berdasarkan hasil penelitian dan pembahasan yang telah diuraikan, maka dapat dikemukakan beberapa saran sebagai berikut:

1. Disarankan guru lebih memperhatikan partisipasi siswa laki-laki maupun siswa perempuan agar seluruh siswa mampu secara aktif mengikuti pembelajaran yang berlangsung dengan baik. 
2. Disarankan guru membiasakan siswa menyelesaikan soal-soal yang diberikan menggunakan langkah-langkah pegerjaan soal yang benar. Dimulai dari menuliskan yang diketahui dan ditanyakan, menuliskan konsep dengan benar, menguraikan jawaban, menuliskan hasil akhir, menuliskan kesimpulan dan mengecek kembali jawaban yang dituliskan.

3. Disarankan guru memberikan variasi soal maupun latihan terhadap topik yang dibahas agar siswa terbiasa memecahkan masalah baru yang mungkin belum pernah ditemukan.

4. Disarankan siswa agar lebih berpikir kritis dalam menyelesaikan masalah matematika

5. Bagi peneliti lain yang hendak mengembangkan penelitian tersebut sebaiknya dapat mengembangkan pada bagian refleksi penelitian dan dapat meninjau lebih dalam mengenai gender karena ada indikasi tiap gender yang memiliki kemampuan berpikir kritis yang berbeda-beda.

\section{Daftar Pustaka}

Anggraeny, T, K, Rohana, R, \& Jayanti, J, J (2019), Pengaruh Pendekatan Metaphorical Thinking terhadap Kemampuan Berpikir Kritis dan Kecerdasan Emosional Siswa SMAN 4 Kayuagung, Jurnal Pendidikan Matematika RAFA, 5(1), 57-69.

Azisah, S, Mustari, A, Himalayah \& Masse, A (2016), Kontekstualisasi Gender Islam dan Budaya. Makassar, Seri Kemitraan Universitas Masyarakan.

De Carvalho, S., F, L (2017), Analisis Kemampuan Siswa dalam Pemecahan Masalah Berbentuk Soal Cerita pada Pembelajaran Matematika Ditinjau dari Segi Gender Pada Materi Segiempat Siswa kelas VII F SMP Negeri 1 Seyegan, Skripsi, tidak dipublikasikan, FKIP Universitas Sanata Dharma, Yogyakarta.
Hendriana, H, Rohaeti, E, E, \& Sumarmo, U (2017), Hard Skills and Soft Skills Matematika Siswa, Bandung, Refika Aditama.

Hidayat, D (2018), Penerapan Reciprocal Teaching untuk Meningkatkan Kemampuan Berpikir Kritis dan Kemandirian Belajar Siswa MA, jurnla derivate, 5(1), 1-8.

Johnson, E, B (2014), Contextual Teaching and Learning Menjadikan Kegiatan Belajar Mengajar mengasyikkan dan bermakna, Bandung, Kaifa.

Junaidi (2017), Analisis Kemampuan Berpikir Kritis Matematis Siswa dengan Menggunakan Granded Response Models di SMA Negeri 1 Sakti, jurnal perspektif gender, 1(4), 14-25.

MZ. Amir, Z, (2013), Perspektif Gender dalam Pembelajaran, Jurnal Perempuan, Agama dan Gender, 12, (1), 14-31.

Nafi'an, M., I (2011), Kemampuan Siswa dalam Menyelesaikan Soal Cerita Ditinjau dari Gender di Sekolah Dasar, Prosiding Seminar Nasional Matematika dan pendidikan matematika, yogyakarta: 571577.

Nawangsari (2008), Pengaruh Kecemasan Ujian terhadap Prestasi Akademik Siswa, Skripsi (Online), Tersedia di http:// WWW. Kecemasanujian/akademik.edu, Diakses pada Tanggal 12 Juli 2020.

Steven, D (2019). Pengaruh Model Poblem Based Learning Terhadap Kemampuan Berpikir Kritis Matematis Perta Didik Kelas VIII SMP Negeri 2 Kendari, Skripsi, tidak diterbitkan, FKIP Universitas Halu Oleo. Kendari.

Suprayitno, A (2018), Analisis Kemampuan Berpikir Kritis pada Materi Bangun Segi Empat Siswa Kelas VII-A SMP Negeri 1 Gondang Tahun Pelajaran 2013/2014, Skripsi, tidak dipublikasikan, IAIN Tulungagung. Tulungagung. 